mines at Mogok, Upper Burma. Chrysoberyl is usually of pronounced colours, the variety alexandrite, for example, being green by daylight and red by lamp-light, and a colourless gem of this species has not previously been recorded.

THE Department of Botany has received more than 2,900 numbers as a result of the British Museum Expedition to East Africa. These were collected by Dr. G. Taylor, assistant-keeper in the Department: some additional numbers collected by Mr. P. M. Synge have not yet arrived. Four groups of mountains were visited-Aberdare, Beringa, Ruwenzori and Elgon. The longest period was spent on Ruwenzori itself, and extensive collections were made in the Namwamba valley up to the snow line: the plants from the adjoining Nyamgassani valley, where Mr. Synge collected, will afford an interesting floristic comparison. Although main attention was paid to the mountains, the flora of the plains was worked so far as possible, and the aquatic flora from the rivers yielded much of interest in relation to researches being carried out in the Department. It is not possible to give an analysis of the collection at present, but it contains several new species and a large number of plants not previously represented in the Museum. The herbarium of William Rashleigh (1777-1855) was recently purchased from a second-hand bookseller. This is entirely of seaweeds and is contained in three volumes. Its main interest is that it contains the herbarium of John Stackhouse (1742-1819) the author of "Nereis Britannica" (1795-1801) in which some of the first post-Linnean genera of algæ were published. Some years ago, an effort was made to trace the herbarium in order to clear up some points which had arisen regarding nomenclature, but nothing could be learned beyond the fact that it had been bequeathed to Rashleigh. The collection was offered for sale in the ordinary way. A small volume of mosses collected by Dr. W. K. Kane on the U.S. Grinnell expedition in search of Sir J. Franklin (1853-55) has been purchased. These were apparently the original set of the "Kane Portfolio" arranged by T. P. James. Most of the cryptogams collected on the expedition were lost when the vessel was abandoned.

\section{Linnean Society of London}

At the anniversary meeting of the Linnean Society of London held on May 24, the president, Dr. W. T. Calman, delivered a presidential address, "The Meaning of Biological Classification". The Linnean Gold Medal was presented to Sir David Prain, a past-president of the Society, in recognition of his services to botany. In making the presentation, Dr. Calman mentioned that Sir David began his scientific work as a member of that great service which has produced so many eminent naturalists, the Indian Medical Service, that he became the head of Indian botany when he was superintendent of the Botanical Survey of India and of the Royal Botanical Gardens, Calcutta. When Sir David returned to England, he became director of the Royal Botanic Gardens at Kew, an office which he filled with conspicuous success until his retirement in 1922 . But although his success as an administrator has been conspicuous, he has never forgotten that the business of a scientific man is scientific research, and his contributions to systematic botany, particularly that of the Indian Empire, are of a kind that would have gladdened the heart of Linnæus himself. The following officers were elected for the year 1935-36: President, Dr. W. T. Calman; Treasurer, Mr. Francis Druce; Secretaries, Mr. John Ramsbottom (botany), and Dr. Stanley Kemp (zoology). The new members of the Council are Dr. B. Barnes, Mr. D. J. Scourfield, Lieut.-Colonel R. B. Seymour Sewell, Mr. W. H. Wilkins and Dr. E. B. Worthington. The president announced that he had appointed the following vicepresidents: Prof. G. D. Hale Carpenter, Mr. Francis Druce, Dr. Margery Knight and Prof. Macgregor Skene.

\section{Temperament in Industry}

Prof. Major Greenwood delivered the second of his Heath Clark Lectures, under the auspices of the National Institute of Industrial Psychology, on May 20, on "Temperaments, Physical and Psychological, in Modern Science". He pointed out that the ancient physicians were deeply conscious that differences of temperament entailed psychological consequences which expressed themselves in bodily as well as mental reactions, and that it was the duty of the physician to diagnose and treat these conditions. In Great Britain the work of Kretschmer has received considerable attention, but the infinitely clearer and scientifically more rigorous work of Boldrino and the Italian School has been unduly neglected. Boldrino has shown that it is probable that certain morphological types, roughly corresponding to the old 'sanguine' and 'melancholics', do differ in resistance to such diseases as tuberculosis, in distribution through the social classes, and even in fertility, but in respect of psychological characters there is much less evidence of any such relation. Prof. Greenwood considered the claims of some modern work on temperament that had relied on statistical correlations : he emphasised that statistical description is fundamentally group-description only, and has little diagnostic value in individual cases. He illustrated this by data on accidents, and showed that, while the application of tests would undoubtedly eliminate many likely to be accident prone, yet they would also eliminate some who are not, and so do an injustice to individuals. Although Prof. Greenwood feels that, with respect to a finer gradation of temperamental qualities, we are indefinitely far from any fool-proof system of routine testing, yet we may be near to the time when an elimination of extreme variants on a basis of temperamental tests will be practicable.

\section{Poisons and their Detection}

Dr. G. Roche LyNch delivered the thirtieth Bedson Lecture in Newcastle-upon-Tyne on May 16. After a brief outline of the history of poisoning from ancient times up to the beginning of scientific 